\title{
Directly Observed Treatment: planning perspectives, improvisation and transfer of policy
}

\author{
Tratamento Diretamente Observado: perspectivas do planejamento, improviso e transferência da política
} Tratamiento Directamente Observado: perspectivas de la planificación, improvisación y transferencia de la política

\author{
Rarianne Carvalho Peruhype', Simone Gomes Costa", Juliana Feliciati Hoffmann", \\ Karen Bissell'", Fernando Mitano ${ }^{\mathrm{IV}}$, Lenilde Duarte de Sáv, Pedro Fredemir Palhal \\ ' Universidade de São Paulo, Nursing School of Ribeirão Preto. Ribeirão Preto, São Paulo, Brazil. \\ "Universidade Federal do Rio Grande do Sul. Porto Alegre, Rio Grande do Sul, Brazil. \\ II' University of Auckland. Auckland, New Zealand. \\ "v Universidade Lúrio, School of Health Sciences. Nampula, Mozambique. \\ ${ }^{v}$ Universidade Federal da Paraíba. João Pessoa, Paraíba, Brazil.
}

How to cite this article:

Peruhype RC, Costa SG, Hoffmann JF, Bissell K, Mitano F, Sá LD, et al. Directly Observed Treatment: practices perspectives, improvisation and transfer of policy. Rev Bras Enferm [Internet]. 2018;71(4):1940-8.

DOI: http://dx.doi.org/10.1590/0034-7167-2017-0493

Submission: 07-04-2017

Approval: 08-31-2017

\begin{abstract}
Objective: to investigate the possibilities of positive and negative association of improvisation and the understanding of what will be the planning by managers and coordinators of tuberculosis control programs, in a context of transference of the Directly Observed Treatment policy. Method: this is a qualitative study, developed through semi-structured interviews analyzed in the light of French Discourse Analysis. Results: there was a weakening of the constructive and operational planning process, which is at the mercy of political will and the need of putting out fires. This, in turn, along with achômetro (Brazilian popular expression used on unsubstantiated point of view or opinion that is based solely and exclusively on the intuition of the person who says it), composed the metaphor of improvisation in its negative perspective, understood by automatism and unsystematization process. Improvisation, however, emerged as a representation of innovation, creativity, and contextual change. Final considerations: both the planning and the transfer of public policies constitute processes that need to be strengthened and qualified in the field of public health.
\end{abstract}

Descriptors: Public Health; Health Planning; Public Policy; Health Management; Tuberculosis.

\section{RESUMO}

Objetivo: investigar as possibilidades de associação positiva e negativa do improviso e a compreensão do que venha a ser o planejamento por gestores e coordenadores dos programas de controle da tuberculose, num contexto de transferência da política do Tratamento Diretamente Observado. Método: estudo qualitativo, desenvolvido por meio de entrevistas semi-estruturadas analisadas à luz da Análise de Discurso de linha francesa. Resultados: observou-se uma fragilização do processo construtivo e operacional do planejamento, que fica à mercê da vontade política e da necessidade de apagar incêndio. Esta, por sua vez, juntamente com o achômetro, compôs a metáfora do improviso em sua perspectiva negativa, compreendida pelo automatismo e assistematização de processos. Num outro momento, entretanto, o improviso surgiu como representação da inovação, da criatividade e da mudança contextual. Considerações finais: tanto o planejamento quanto a transferência de políticas públicas constituem-se em processos que precisam ser fortalecidos e qualificados no âmbito da saúde pública.

Descritores: Saúde Pública; Planejamento em Saúde; Política Pública; Gestão em Saúde; Tuberculose.

\section{RESUMEN}

Objetivo: investigar las posibilidades de asociación positiva y negativa del improviso y la comprensión de lo que venga a ser la planificación por gestores y coordinadores de los programas de control de la tuberculosis, en un contexto de transferencia de la política del Tratamiento Directamente Observado. Método: estudio cualitativo, desarrollado por medio de entrevistas 
semiestructuradas analizadas a la luz del Análisis de Discurso de línea francesa. Resultados: se observó una debilitación del proceso constructivo y operacional de la planificación, que está a merced de la voluntad política y de la necesidad de apagar el fuego. Esta, a su vez, junto con el creometro, compuso la metáfora del improviso en su perspectiva negativa, comprendida por el automatismo y la asistematización de procesos. En otro momento, sin embargo, el improviso surgió como representación de la innovación, de la creatividad y del cambio contextual. Consideraciones finales: tanto la planificación como la transferencia de políticas públicas se constituyen en procesos que necesitan ser fortalecidos y calificados en el ámbito de la salud pública. Descriptores: Salud Pública; La Planificación en Salud; Política Pública; Gestión en Salud; Tuberculosis.

\section{CORRESPONDING AUTHOR Rarianne Carvalho Peruhype E-mail: rarianne@usp.br}

\section{INTRODUCTION}

The Situational Strategic Planning (SSP) was created in the 1970s by the Chilean economist Carlos Matus and has been widely used in health in Brazil and South America ${ }^{(1)}$. The assumption of this planning is the insertion of the various actors in the decision-making process, being composed of four operational moments: the explanatory (detection and investigation of the problem), normative (decision of what to do in political time and space), strategic (analysis of the strategies to be adopted and feasibility, among others) and the tactical operation (step of operationalization and improvement of the plan) ${ }^{(2)}$.

We recognize, in fact, planning as an important management tool; however, we still see cultural inconsistency linked to its use $\mathrm{e}^{(3)}$. Frequently, we observed a certain difficulty on the part of coordinators, managers and professionals regarding the strategic planning of actions in the most diverse health contexts. In the organization of the transfer of the policy of the Directly Observed Treatment (DOT) of Tuberculosis (TB) in Porto Alegre city, for example, it was possible to observe an initial and sometimes a non-existent planning regarding this process ${ }^{(4)}$. DOT can be understood as a daily follow-up (by health professionals, family members or any other trained person) of patients' medication intake ${ }^{(5)}$. As it is known, $90 \%$ of TB cases is cured through the correct use of medications ${ }^{(6)}$; therefore, DOT is an important strategy for adherence and reduction of a possible drug resistance, not to mention that it is also emphasized in the international END TB strategy, aimed at combating the epidemic of the disease throughout holistic interventions in social and health fields by qualifying universal access and strengthening preventive, diagnostic and curative measures, among others ${ }^{(7)}$.

The transfer of public policy can be understood as the process in which "[...] knowledge about policies, management measures, institutions, etc. in a time and/or place is used in the development of policies, management measures and institutions in another time and/or place ${ }^{\prime \prime(8)}$. A plenty elements permeate this process, such as the different intercommunicating levels involved (global, national, etc.), contextual variables (political, economic, social, cultural), availability of resources (financial, human, others), network, actors, communication channels, among other aspects ${ }^{(9)}$. It is a routine process in health, since we often incorporate in the institutional machine procedures and public policies of different levels, states and nations. In addition, the analysis of the transfer allows shaping and (re) structuring policies, being therefore, a key element in the identification of success and failure in the process of implementing them ${ }^{(10)}$.
Thus, the importance of properly transferring a public policy, the positive impact of a qualified operationalization and the absolute necessity of including the theme in the schedule of managers and coordinators of public programs, making us want to analyze more closely how the planning of this process occurs, starting from the assumption that its improper implementation or its absence can negatively influence the results as a whole ${ }^{(4)}$. Thus, when we consider the reported commencement, and sometimes, the absence of DOT transfer planning in the capital of Rio Grande do Sul State, we initially wonder how coordinators, managers and health secretary of this municipality understand the concept of planning and there are indications that this activity is linked to the practice of improvisation in this context.

In fact, planning all the details of human existence is an impractical task, not to mention that, historically, improvisation has become an important component for society when one searches for innovation in varied contexts. In arts, improvisation is the fundamental strategy for the success of a play in which an actor, for example, forgets the discourse ${ }^{(11)}$. In music, it becomes a practice that "favors the instantaneous performance of musical thought; the one who improvises must think during the activity and engage in a process that demands continuous realization of musical impulse"(12). In public health, however, the use of this device may be associated with mismanagement, malpractice and, in many contexts, rework, that is the result of immediacy, the adoption of inappropriate measures and Freudian slips ${ }^{(13)}$.

\section{OBJECTIVE}

To investigate not only the possibilities of positive and negative associations of improvisation, but also the tension between knowing/not knowing how to plan, and the understanding on the meaning of planning by managers and coordinators of TB control program in a given context of policy transfer of the DOT. Because it is an unheard of subject, it is believed that its importance lies not only in the possibility of strengthening scientific evidence on the subject, but also as an object of qualification of the professional and management practice in the public health.

\section{METHOD}

The present work was based on the Consolidated Criteria for Reporting Qualitative Research (COREQ) checklist ${ }^{(14)}$ as a guide for the description of elements and stages developed. 


\section{Ethical aspects}

This research was submitted and approved by three Research Ethics Committees (CEPs), being those of the College of Nursing, University of São Paulo at Ribeirão Preto Campus (EERP/USP), the Grupo Hospitalar Conceição (Conceição Hospital Group) and of the Municipal Health Secretariat (MHS) of Porto Alegre city. In addition, the collection of data was authorized in all institutions and the inclusion in the study with the consent of volunteers subjects, expressed in the signing of the Informed Consent, was respected.

Type of study and theoretical and methodological frameworks

This is a qualitative study, developed through semi-structured interviews analyzed in the light of the French Discourse Analysis (DA). The DA holds a multidisciplinary approach, composed of the Linguistics (the language understood not as an abstract system, but as a way of meaning, of producing meaning), Psychoanalysis (under the aegis of the subject of the unconscious) and of Marxism (with historical and dialectical materialism, the subject affected by history and ideology) ${ }^{(15)}$. It should be pointed out that the DA is fundamentally concerned with an in-depth analysis of the research object, in a vertical way, so to speak, not dwelling on the horizontal exhaustion, that is, on all the material of analysis ${ }^{(15)}$, which means that a single discursive sequence (DS) may be enough to develop the study, provided that its analysis meets the pre-established objectives of the work.

\section{Methodological procedures}

The analysis of the French Discourse Analysis involves the following steps: the transition from the surface linguistic to the discursive object, that is, an inverse process of surface, with a more general initial analysis of the object; the transition from the discursive object to the discursive formation, which outlines the affiliations, the networks of meaning and the relationship with the discourse (what was said, what was not said, what could be said, etc.); and the transition from the discursive process to the ideological formation, whose focus is the correlation of meanings, the process of meaning itself, the metaphorical effects, among others ${ }^{(15)}$.

\section{Study scenario}

The research was carried out between 2013 and 2014, with all coordinators of the TB Control Programs in Porto Alegre city (at municipal and state levels and the Grupo Hospitalar Conceição - Conceição Hospital Group), as well as with the respective District Health Secretary. The capital of the state of Rio Grande do Sul currently has 1,416,714 inhabitants ${ }^{(16)}$ and stands the first positions in the ranking of the Brazilian capitals with the highest incidence and mortality due to TB (80.4 and 3.9 per 100,000 inhabitants, respectively), which makes the investment and the qualification of processes and strategies aimed at controlling the disease in its territory ${ }^{(17)}$.

\section{Source, collection and data organization}

Five subjects were selected intentionally. The interviews were conducted by the main author of the research. The initial contact with the research subjects was carried out via telephone and e-mail, with the purpose of establishing a visitation schedule, as well as explaining the reasons for the proposal's development. The interviews took place individually and face-to-face in their work environment, with the support of a semi-structured script that had issues related to the conceptualization of planning, its importance in general, and the transfer of a public policy on the methodology of construction and operationalization of its stages in the services and also on the transfer of DOT, on the engagement of other actors in the process, among others. There was no refusal by any subject regarding participation in the present study.

\section{Data analysis}

The reflective process was carried out jointly by all authors, considering the data collected, the temporal, socio-historical context and the discourse production. Thus, after the organization of the corpus of the research, consisting of DS from the raw empirical material, three main discursive blocks of analysis emerged, being: Conceptualization of the activity planning by the manager and the coordinator, Importance of health planning and the process of transfer of a public policy and Improvising in the management: innovation, the theory of putting out fires and achômetro.

\section{RESULTS}

Next, the three discursive blocks are presented, as previously explained.

\section{Conceptualization of the activity planning by the manager and the coordinator}

The subjects, when asked about their understanding/comprehension/significance of planning, as general, answered as follows:

Well, planning is actually outlining steps, paths you will follow to reach your goal, right? [...]. (Subject 1)

[...]so, this way, every and any project I have to carry out I have to foresee everything that is involved since the moment of setting up a stream, routine, providing subsides for the implementation of that work, that Project, making communication easy in order to solve doubts, finally, pondering [...]. (Subject 3)

Well, is putting things, hmm, in an orderly manner to develop actions within a period of time, and inside this and within that orderly manner, so to speak, to be delimiting well the actions that will be performed, the objectives of these actions and who will carry them out and in what time [...]. (Subject 4)

[...] It is fundamental, ok? This is a well-done planning from what, what is expected, goals, indicators and work with welldone protocols, properly disseminated, right? For everyone involved in the technical areas and areas of practice that create the permanent actions [...]. (Subject 5)

When the questions started in order to understand, from the point of view of the subject interviewed, the importance given to the health activity planning in the elaboration of an operational plan to transfer a public policy at the different levels 
of government, we obtained some points of tension, as seen in the next discursive block.

\section{Importance of health planning and the process of transfer of a public policy}

[...] So, for creating the plan we have exquisite planners, so this is not the problem, the problem is the politics' will, we don't have a politics' will measurer and we cannot know if it will be well met or not [...]. (Subject 2)

I believe that in the health area planning is not appreciated or comprehended. We have here, I will speak in the name of our place, a very large dichotomy between who understands about financial resource, who creates the planning for performance of the resource through projects and who implements the project, where one doesn't understand very much the role of the other, right? [...]. (Subject 3)

In my opinion, managers that are more tied to political issues, hmm, the situation is very complex. We have a lot of difficulty in talking about making bigger plans, in public health, we are often putting out fires, so within that it happens [...]. (Subject 4)

Regarding the linkage of the planning activity and the improvisation practice, some DS were selected in which the subjects leave evidence of a possible coexistence and, also, overlapping from one activity to the other in some health spheres, as observed in the sequence:

\section{Improvising in the management: innovation, the theory of "putting out fires" and "achômetro"}

It's annually, of course there are many things happening daily, you will be working with the teams, but the plan as a whole is annually reviewed [...]. (Subject 1)

I've done it a few times, making the plan, showing the plan, approving the plan, people agreeing, managers saying it's great, but at the time to implement and follow the schedule, it doesn't happen, then things are being left out, a fire comes up here a fire there in terms of health [laughs], and the resources are moved to there [...]. (Subject 2)

[...] Now, as things become more, in quotation marks, hidden and asleep, are often unplanned, because they will, we will be doing some actions, $h m m$, let's say that a big problem with tuberculosis and HIV is broadcasted by the media, then putting out fires is needed, but in terms of having a long-term situation is already more complex [...]. (Subject 4)

Well, planning is, [laughs] means everything, right? [...] you can't, you can't simply doing it using the achômetro, right? You need some data [...]. (Subject 5)

[...] Either you have a very well done plan, you convince others that it is the ideal, and people don't suggest any change or you listen to them and makes changes to adapt to the local reality, but planning is fundamental, as one action that you cannot work only by guessing [...]. (Subject 5)
The following is an analysis of the discursive nuances and the different positions assumed by the subjects in the selected DS.

\section{DISCUSSION}

There are several possible definitions of planning. Matus, once defined it as "thinking before acting, thinking systematically, with a method; explaining each of the possibilities and analyzing their respective advantages and disadvantages; proposing objectives"(18). Others define it as a "form of organization for action" ${ }^{199}$ or, in common sense, as an intervention capable of "organizing activities, seeking better results, reducing conflicts and uncertainties"(20).

In this way, the positioning of managers/coordinators indicates the existence of a conceptual understanding of what is to be planned, reinforced by the use of expressions that refer to this practice (outlining the steps, the paths, foreseeing everything that is involved, providing the subsidies for the implementation, outlining actions well, ordering) and some of its constituent elements (goals, indicators, protocols, objectives, etc.).

In fact, there is evidence that it is not a difficulty in understanding the concept of planning by Primary Health Care coordinators, for example, but typically in the operationalization of such activity $^{(21)}$, in which is pondered not only a notorious deficit in its development, but also in the evaluation of services itself ${ }^{(22)}$. This deficiency, coupled with the commencement of the theme of public policy transfer in the Brazilian academic environment ${ }^{(23)}$, leads us to a better understanding of why planning in the transfer of DOT, as an example, has been characterized as incipient practice and sometimes nonexistent, as previously mentioned ${ }^{(4)}$, a reality that possibly extends to the process of transferring other policies within the Brazilian Unified Health System (SUS).

Still, if we consider the statements that planning is fundamental (...), means everything (...), finally, pondering (...), we can deduce that its weakening and, sometimes, non-existence, tends to mean a break in the logical chain of resolution of the problems of health institutions, as well as an organizational disqualification of processes, the consequences of which may extend to the achievement of goals, as well as to the worsening of health and disease indicators of the population. If the daily work of the public health manager is naturally composed of programming actions, planning and definition of goals and objectives, it can be said that the regulatory activities of audit, process or results, will certainly be influenced in function the existence or not of such definitions ${ }^{(20)}$.

In addition, it is known that as an important management tool, planning allows managers to better follow the work other professionals under their responsibility, who see in this a framework of clear and explicit purposes of implementation. If well disseminated, planning tends to reduce alienation, since there is a greater recognition of the importance of the work developed, opening precedents to mobilize wills, transform situations and strengthen the democratic process ${ }^{(24)}$.

Planning can still function as a device that allows the establishment of agreements and commitments based on priorities ${ }^{(19)}$. Given such considerations, it can be said by discursive context that there is a recognition and awareness of the coordinators/ managers about the importance of socializing and diffusing 
this practice and the product from it, when is observed, for example, the saying: "to work with, with well-done protocols, are properly disseminated for everyone involved in the technical areas and areas of practice that create the permanent actions...".

However, even in view of the importance of this activity, it should be noted that situational planning is still not well appreciated at the various levels of management ${ }^{(25)}$. Due to the bureaucratization of this activity in the SUS (requirements in its formulation, existence of an endless number of ordinances, norms, pacts, etc.) and of its use, in certain occasions, to attract resources, it has been transformed in a practice adjective as ritualistic and theoretical, without great commitments with the resolution of the problems in fact $^{(24)}$. Another, that analyses of historical series have also demonstrated limitations and problems in the habitual use of planning, for example, the instrumental logic, the loss of the historicity of the process, the emptying of meaning and the respect and valorization of false assumption ${ }^{(19)}$.

A research conducted with managers from 15 municipalities of the Zona da Mata (The Zona da Mata is the narrow coastal plain between the Atlantic Ocean and the dry "agreste" and "sertão" regions in the northeastern Brazilian states of Maranhão, Piauí, Rio Grande do Norte, Paraíba, Pernambuco, Alagoas, Sergipe and Bahia) in Minas Gerais State aimed to investigate the difficulty in planning in the basic sanitation area, whose repercussions not only cover the qualified management of services, but above all, public health. As a result there was unavailability in financial resources, technical capacity and loss of professional qualifications, compromise of sectoral integration and absence of political will(26).

In the scope of the transfer of policy of the DOT, the subjects, when asked about the importance of planning in the meantime, and in general in their conception, also asserted the absence of appreciation of the activity according to the political will question (“... the problem is the politics' will, we don't have a politics' will measurer and we cannot know if it will be well met or not..."), the commitment of the communicative process and the fragmentation of services that operationalize this activity. This can be evidenced, for example, in the discursive tension of the noun "dichotomy" and the adjective "very large", in which there is no reciprocal understanding of the roles played by those who plan, deal with the financial resources and who carry out the projects.

Subject 4 reinforces this idea by stating the contextual complexity when it comes to the involvement of political issues in this area, and also when it addresses the difficulty in planning and executing dialogue, touting the practice of improvisation, making metaphors with putting out fires, by saying "(...) in public health we are often putting out fires, then within what happens (...)".

Thinking initially in "planning" and "action", we bring to the discussion a neuralgic point in the field of health policy, planning and management (PP\&M). Studies that address these areas and their contents in a historical and epistemological perspective have not been observed. Considering the fact that theoretical and practical interlocution (influenced by epistemological criticism), and the very process of experimenting with models and methods as inherent singularities in this field, we understand more easily the natural tendency to seek technological development through the mediation of what is conceptual/ instrumental and the action of the subjects in health institutions, their problems, needs and demands ${ }^{(27)}$.

In view of the above, it is also urged here to carry out studies with this perspective of historical/epistemological deepening in what concerns the field of planning and its connection with the reference of the transfer of public policies, either through the exploitation of few national academic references of the issue in the field of health, or by the appropriation of the international literature, in spite of the latter case, the adaptation to the Brazilian reality. Again, the inseparability of theory and practice is strengthened, when one intends to experiment, construct, adapt and test new propositions.

It is important to emphasize, however, that we start from the point of view that theory/practice together must occur in two crucial moments: the first with the theoretical appropriation of the issue and the formulation of the planning for the transfer of public policy, and the second with the operationalization of this plan and the consequent theoretical adaptation of the theme. Steps were both simultaneous and complementary.

When we deal with the reality of improvisation we start from an approach of different perspectives, a negative of the lack of systematization and the positive one of innovation. Matus, in his notes on planning, said that "either we know how to plan or we are doomed to improvisation. It is the visible hand that explores possibilities in circumstances in which the 'invisible hand" is incompetent or does not exist"(18), further said that "planning is not a disposable method; it is a way that man lives towards freedom. The alternative to the plan is improvisation or resignation; it is the renunciation to gain more freedom"(28).

Subjects 2 and 4 , for example, bring in their discourses the improvisation in this negative perspective in the planning and transfer of public policy, when they make metaphors with putting out fires. The first one, when you say "managers saying it's great, but at the time to implement and follow the schedule, it doesn't happen, then things are being left out, a fire comes up here a fire there in terms of health [laughs], and the resources are moved to there" reinforces not only the breakdown in theory/practice, plan/action ("things are being left out"), but also increases the possibility of failure of the visible hand and emphasizes amateurism and improvisation in management, two characteristics typically known in Brazil ${ }^{(29)}$. Putting out fires and the unplanned transfer of financial resources also point to the very fragility of the planning, since the latter, as a rule, proposes not only to work on the aspect of financial viability, but also to guide investments and allocate resources efficiently ${ }^{(20)}$.

There was a metaphor made with putting out fires has already on other occasions, such as prioritizing the resolution of the demands of the moment, which hinders the process of establishing other service priorities ${ }^{(30)}$. This automatism in prioritization and decision-making was triggered, for example, by the "media", in Subject 4's speech, when he stated "we will be doing some actions, hmm, let's say that a big problem with tuberculosis and HIV is broadcasted by the media, then putting out fires is needed". Not only the outlines of constant hesitation in subject speech (successive repetitions of the term $\mathrm{hmm}$ ), but especially the signifier "in quotation marks" extol an important tension point of the discourse: hidden and asleep things, 
whose polysemy sense may run from the planning of transfer of the DOT policy to the historical memory of TB, as a secular disease, which is known to be neglected, and even with cure is still considered the most infectious disease in the world ${ }^{(31)}$.

Another signifier of improvisation in its negative perspective is associated with the term achômetro, as stated by Subject 5 . Failure to do so using the achômetro reinforces the view that complexity, endless demands, lack of health resources, and quality required in the provision of services do not match with the risk of improvisation, thus allowing, in this context, the indispensability of planning(32).

However, the facts show that both the precariousness of planning and the política do improviso (freely translated as policy of improvisation) in its deconstructive character still predominate in municipal public management, especially in small municipalities, which does not mean, however, that they do not occur in those held as greater. By policy of improvisation is meant the adoption of governmental measures as opposed to what was planned, driven by private and governmental interests and/or due to daily urgencies. The pre-established goals are no longer achieved, since planning is overlooked by managers, who in turn prefer to satisfy a given political clientele. Finally: "facts that result in forgotten plans, and consequently cause discontinuity of planned actions" ${ }^{\prime \prime 3)}$. It can be said, therefore, that the policy of improvisation conceptually accepts the theory of putting out fires, the prioritization of daily urgencies, and the practice of the achômetro by rejecting the elaboration and implementation of the plan.

In another perspective, improvisation can symbolize innovation, creativity. Some authors consider that in improvisation, the deliberate process in acting for change does not necessarily require a prior plan, but it matches the organizational resources available to achieve new results. For others, the characteristics of an improvised situation can be planned, but in an unforeseeable way, for example, in which the actor of change is forced to adjust his/her activities through the occurrence of unforeseen events. There are those who say that improvisation, as an element of organizational change, can vary in its form of occurrence, from momentary actions to completely planned actions, and can occur at the individual as well as collective level ${ }^{(34)}$.

In the conception of the new from the improvisation, we try to consider this (re) construction not only from the institutional resources already available, but also from something already structured, organized, planned, in which, due to the occasion, new and different elements in the operational and transforming process. As, for example, a musician who does not hesitate in improvising when necessary, but holds the theoretical knowledge of the instrument he/she plays, leading the change in a harmonic and not unstructured way, which could affect the musical arrangement. In this context, we also cite the possibility of composing musical pieces by means of musical variation, a process in which the initial material of the issue, for example, undergoes various procedures such as transposition, downgrading, diminution, among others, nevertheless always keeping its essential, genuine characteristics ${ }^{(35)}$.

In our discursive contexts, Subject 1 shows evidence of this structured construction which we refer to when responding as follows about the periodicity of the evaluation of the plan: "(...) It's annually, of course there are many things happening daily, you will be working with the teams, but the plan as a whole is annually reviewed (...)". As noted, there is a plan set, there is a periodicity of evaluation and there are unforeseen daily situations that require adaptations and improvisations ("there are many things happening daily, you will be working with the teams"), but here coordinator and the team knows where one wants to reach, what one wants to achieve and the path one must tread, so that fires that put out function in the figurative sense of renewal to this path, strengthened by the advent of the creative and innovative element.

In a hospital-centered context, health professionals (nurses, for example) can use their knowledge and available institutional resources to improvise solutions that circumvent possible harm to patient care by creatively innovating their practice with a determined purpose in order to benefit the user ${ }^{(36)}$. The problem is that when thinking about planning, the Cartesian doubt that strengthens it is often imbued with the strong characteristics of conservatism that precludes innovative practices, completely neglecting the process of intuition, which is based largely on experience ${ }^{(37)}$.

The fact is that if there is a conservative, and sometimes, authoritarian planning aimed at maintaining the status quo in the area of medical and curative health, it is also present in its hegemonic model in the areas of collective health, prioritizing technocratic action, political direction and economic conception. The counter-hegemonic proposal, which is strengthened in this work, in turn, implies transformative planning, free from the shadowy, dominant and political interests, and the biases of economic power. Its logic is based on the coproduction of needs, on the autonomy of the subject and on the collective capacity, in which freedom, action, intervention and transformation "of the objectively constructed reality", intervening conscientiously in the construction of history ${ }^{(38)}$. In this sense, improvisation in its positive, subjective, sustained and intuitively, enriched by a prior knowledge can become of great value in the quest for transformation through innovation.

Finally, for some, it is still not possible the coexistence of the inflexible with the new one in the management scope, as exemplified in saying:

[...] Either you have a very well done plan, you convince others that it is the ideal, and people don't suggest any change or you listen to them and make changes to adapt to the local reality, but planning is fundamental, as one action that you cannot work only by guessing. (Subject 5)

The planning as essential (fundamental) does not allow being associated neither with improvisation nor in its negative form, reflected in the practice of the achômetro ("you cannot work only by guessing"), nor in the positive one. The very dichotomy of discourse, reiterated by the alternative conjunction or, leaves clues that rigid planning (in which "people don't suggest any change") does not coexist with the innovator, possibly coming from a positive improvisation ("changes to adapt to the local reality"); or one, or the other. However, we must consider that the new in many contexts does not become only a possible alternative, rather a pressing need given the conjuncture in which we live of continuous transformation as a lever of progress. 
In addition, it is worth noting that it is of little use to understand planning and its importance in public management and health processes, if there is still a deficiency in its operationalization, strengthened at times by the absence of political will, sometimes by the practice of improvisation, by the use of "achômetro" and prioritization of "putting out fires", as we could observe with regard to the transfer of the DOT policy. However, when we consider the seriousness of TB in Porto Alegre city and the benefits derived from DOT practice, we will be able to perceive that these organizational gaps in the processes - either planning or the transfer of policy - can contribute decisively to the achievement of goals and the desired improvement in population health indicators.

\section{Study limitations}

Some elements from the work environment recorded at the time of the interview may have influenced the answers of participants, such as interruptions (colleagues, telephone), work overload and the fight against time to perform tasks, besides the characteristic arrangement of shared environments of some tables and seats, which may have generated some kind of inhibition of participation.

\section{Contributions to the Nursing}

Professional nurses are delegated diverse functions in the performance of their activity, which include not only those focused on assistance practice, but also the training of human resources, the coordination of teams, programs and policies in public management, among others. Areas that, of course, involve processes of transfer of policy and planning, which in themselves will require knowledge of nurses, as well as the development of technical-scientific skills, competencies and qualities necessary for the good performance of such activities and within the reach of goals, thus reducing the use of improvisation at its negative perspective. Such improvement can occur through diversified means, such as in continuing education actions, in training, or by strengthening the subjects in undergraduate and postgraduate courses in the area. This qualification tends, above all, to reflect positively in the whole practical and operative context of this professional, including that focused on TB control.

\section{FINAL CONSIDERATIONS}

The importance and benefits of health planning are undeniable. Similar reasoning can be employed when the purpose is to think of the transfer of a public policy in that context. We stress, however, the importance of adopting transformative, unfettered planning that opens up to the innovative, the intuitive and the subjective, often expressed in a positive improvisation.

In response to the objectives established in the present work, it was observed that there is an understanding of what the planning is and possibly a link between the proposed plan and improvisation in its positive meaning. However, it can be seen that putting out fires and the achômetro still play an important role as a daily practice and present in the routine of managers and coordinators of public health programs, often reflecting automatism, unsystematization, unpreparedness of the institutional machine and abandonment of the previously idealized plan. Refuting the unpredictable is to deny the very mechanisms of life; the difference lies precisely in approaching it with the conceptual, organizational and structural alignment required by the situation.

\section{REFERENCES}

1. Darosi GCM. Analysis of scientific production about strategic planning situation. RBADM. 2014;5(1):370-83.

2. Rieg DL, Scramim FCL, Raimundo DO, Zau VC, Calazans WR. Using the situational strategic planning methodology for structuring problems in the private sector: multiple-case studies. Gest Prod[Internet]. 2014[cited 2018 Feb 24];21(2):417-31. Available from: http://www.scielo.br/pdf/gp/v21n2/v21n2a14.pdf

3. Silva BFS, Wandekoken KD, Dalbello-Araujo M, Benito GAV. The relevance of planning as management practice in health micro region of São Mateus-ES. Saúde Debate[Internet]. 2015[cited 2018 Feb 25];39(104):183-96. Available from: http://www.scielo.br/ pdf/sdeb/v39n104/0103-1104-sdeb-39-104-00183.pdf

4. Peruhype RC. The planning and transfer of the Directly Observed Treatment of Tuberculosis policy in the municipality of Porto Alegre - RS[Tese][Internet]. Escola de Enfermagem de Ribeirão Preto da Universidade de São Paulo. 2015 [cited 2018 Feb 25]. Available from http://www.teses.usp.br/teses/disponiveis/22/22133/tde-16062015-184557/pt-br.php

5. Freitas IM, Crispim JA, Pinto IC, Villa TCS, Brunello MEF, Pinto PFPS, et al. Knowledge and perception about Tuberculosis of patients ' families under Directly Observed Treatment at a health service in Ribeirão Preto-SP, Brazil. Texto Contexto Enferm[Internet]. 2012[cited 2018 Feb 26] 21(3):642-9. Available from: http://www.scielo.br/pdf/tce/v21n3/en_v21n3a20.pdf

6. World Health Organization-WHO. Stop TB Partnership. The Global Plan to stop TB 2011-2015: transforming the fight towards elimination of tuberculosis[Internet]. Geneva: WHO; 2015[cited 2016 Sep 21]. Available from: http://www.stoptb.org/assets/ documents/global/plan/TB_GlobalPlanToStopTB2011-2015.pdf

7. World Health Organization-WHO. Implementing the END TB Strategy: the essentials[Internet]. 2015[cited 2017 Aug 10]. Available from: http://www.who.int/tb/publications/2015/end_tb_essential.pdf

8. Dolowitz D, Marsh D. Who learns what from whom: a review of the Policy Transfer literature. Polit Stud[Internet]. 1996[cited 2018 Feb 26]XLIV:343-57. Available from: http://onlinelibrary.wiley.com/wol1/doi/10.1111/j.1467-9248.1996.tb00334.x/full 
9. Bissell K, Lee K, Freeman R. Analysing Policy Transfer: perspectives for operational research. Int J Tuberc Lung Dis[Internet]. 2011[cited 2017 Aug 08];15(9):1140-8. Available from: http://www.ingentaconnect.com/content/iuatld/ijtld/2011/00000015/00000009/art0 0003; jsessionid = 1o2rga995f1 rr.x-ic-live-01\#

10. James O, Lodge M. The limitations of 'Policy Transfer' and 'Lesson Drawing' for public policy research. Polit Stud Rev[Internet]. 2003[cited 2017 Aug 08];1(2):179-93. Available from: http://onlinelibrary.wiley.com/doi/10.1111/1478-9299.t01-1-00003/full

11. Spolin V. Improvisação para o teatro. São Paulo: Perspectiva; 2003.

12. Santiago PF. The integration of deliberate practice and informal practice in instrumental music learning. Per Musi[Internet]. 2006[cited 2018 Feb 26];(13):52-62. Available from: http://musica.ufmg.br/permusi/port/numeros/13/num13_cap_04.pdf

13. Barbosa RV. Custos na gestão pública: teoria e práticas[Monografia][Internet]. Universidade do Extremo Sul Catarinense-UNESC. 2014[cited 2018 Feb 27]. Available from: http://repositorio.unesc.net/handle/1/3251

14. Tong A, Sainsbury P, Craig J. Consolidated criteria for reporting qualitative research-COREQ: a 32-item checklist for interviews and focus groups. Int J Qual Health Care[Internet]. 2007[cited 2017 Aug 10];19(6):349-57. Available from: https://edisciplinas.usp.br/ pluginfile.php/150202/mod_resource/content/1/COREQ.pdf

15. Orlandi EP. Análise de discurso: princípios e procedimentos. 10.ed. Campinas: Pontes; 2012.

16. Brasil. Ministério da Saúde. Departamento de Atenção Básica. Histórico de Cobertura da Saúde da Família[Internet]. 2017[cited 2017 Aug 08]. Available from: http://dab.saude.gov.br/portaldab/historico_cobertura_sf.php

17. Brasil. Ministério da Saúde. Secretaria de Vigilância em Saúde. Indicadores prioritários para o monitoramento do Plano Nacional pelo Fim da Tuberculose como problema de Saúde Pública no Brasil. Bol Epidemiol[Internet]. 2017[cited 2017 Aug 08];48(8). Available from: http://portalarquivos.saude.gov.br/images/pdf/2017/marco/23/2017-V-48-N-8-Indicadores-priorit--rios-para-omonitoramento-do-Plano-Nacional-pelo-Fim-da-Tuberculose-como-Problema-de-Sa--de-P--blica-no-Brasil.pdf

18. Huertas F. O método PES: entrevista com Matus. São Paulo: FUNDAP; 1996.

19. Campos RO. O planejamento no labirinto: uma viagem hermenêutica. São Paulo: HUCITEC; 2003.

20. Brasil. Ministério da Saúde. Manual de planejamento no SUS[Internet]. Brasília: Ministério da Saúde. 2016 [cited 2017 May 26]. Available from: http://bvsms.saude.gov.br/bvs/publicacoes/articulacao_interfederativa_v4_manual_planejamento_atual.pdf

21. Oliveira CAF. Compreensão do planejamento por enfermeiros das equipes da Estratégia Saúde da Família[Dissertação][Internet]. Centro de Ciências Biológicas e da Saúde da Universidade Federal de São Carlos-UFSCAR. 2015[cited 2018 Feb 24]. Available from: https://repositorio.ufscar.br/handle/ufscar/7758

22. Lorenzetti J, Lanzoni GMM, Assuiti LFC, Pires DEP, Ramos FRS. Health Management in Brazil: dialogue with public and private managers. Texto Contexto Enferm[Internet]. 2014[cited 2018 Feb 27];23(2):417-25. Available from: http://www.scielo.br/pdf/tce/ v23n2/0104-0707-tce-23-02-00417.pdf

23. Farah MFS. Disseminação de inovações e políticas públicas e espaço local. Organ Soc[Internet]. 2008[cited 2018 Feb 27];15(45):10726. Available from: http://www.scielo.br/pdf/osoc/v15n45/v15n45a09.pdf

24. Paim JS. Planejamento em saúde para não especialistas. In: Campos GW. Tratado de Saúde Coletiva. Rio de Janeiro: HUCITEC/ FIOCRUZ; 2006. p. 767-782.

25. Araújo MBS, Rocha PM. Teamwork: a challenge for family health strategy consolidation. Ciênc Saúde Colet[Internet]. 2007[cited 2018 Feb 27];12(2):455-64. Available from: http://www.scielo.br/pdf/csc/v12n2/a22v12n2.pdf

26. Lisboa SS, Heller L, Silveira RB. Challenges of municipal planning for basic sanitation in small size municipalities: the managers' perception. Eng Sanit Ambient[Internet]. 2013[cited 2018 Feb 25];18(4):341-8. Available from: http://www.scielo.br/pdf/esa/ v18n4/1413-4152-esa-18-04-00341.pdf

27. Paim JS, Teixeira CF. Policy, planning and health management: the current understanding. Rev Saúde Públ[Internet]. 2006[cited 2018 Feb 24];40(Esp):73-8. Available from: http://www.scielo.br/pdf/rsp/v40nspe/en_30625.pdf

28. Matus C. Política, Planejamento \& Governo. Brasília: IPEA; 1993.

29. Lyra TM, Araújo Jr JLAC.[Policy analysis: study of puclic policy of environmental health in a metropolis of northeastern Brazil]. Ciênc Saúde Colet[Internet]. 2014[cited 2018 Feb 24];19(9):3819-28. Available from: http://www.scielo.br/pdf/csc/v19n9/14138123-csc-19-09-3819.pdf Portuguese

30. Bazzo-Romagnolli AP, Gimenez-Carvalho B, Almeida-Nunes EFP. Management of the Basic Health Unit in small municipalities: instruments, facilities and related difficulties. Rev Gerenc Polit Salud[Internet]. 2014[cited 2018 Feb 25];13(27):168-80. Available from: http://www.scielo.org.co/pdf/rgps/v13n27/v13n27a10.pdf

31. Maciel ELN. Post-2015 agenda strategies for tuberculosis control in Brazil: challenges and opportunities. Epidemiol Serv Saúde[Internet]. 2016[cited 2018 Feb 25];25(2):423-6.Available from: http://www.scielo.br/pdf/ress/v25n2/en_2237-9622-ress-25-02-00423.pdf

32. Mendes VAP. Planejamento e gestão em saúde: análise do planejamento do conselho nacional de Saúde, 2013-2015[Monografia] [Internet]. Universidade de Brasília. 2013[cited 2018 Feb 24]. Available from: http://bdm.unb.br/handle/10483/7892

33. Ramos MRG. Desafios da concretização do Planejamento Estratégico Governamental em âmbito municipal[Monografia][Internet]. Universidade Tecnológica Federal do Paraná-UTFPR. 2012[cited 2018 Feb 26]. Available from: http://repositorio.roca.utfpr.edu. 
br/jspui/bitstream/1/1568/1/CT_GPM_II_2012_05.pdf

34. Nóbrega DL. Improvisação e mudança organizacional durante a implementação de sistema integrado de gestão: a voz do usuário[Dissertação][Internet]. Centro de Ciências Sociais e Aplicadas da Universidade Federal da Paraíba-UFPB. 2009 [cited 2018 Feb 27]. Available from: http://tede.biblioteca.ufpb.br/handle/tede/3868?locale=pt_BR

35. Bastos RJM. Música nas sociedades indígenas das terras baixas da América do Sul: estado da arte. MANA[Internet]. 2007[cited 2018 Feb 27];13(2):293-316. Available from: http://www.scielo.br/pdf/mana/v13n2/01.pdf

36. Santos EI, Gomes AMT, Oliveira DC. Representations of vulnerability and empowerment of nurses in the context of HIV/AIDS. Texto Contexto Enferm[Internet]. 2014[cited 2018 Feb 26];23(2):408-16. Available from: http://www.scielo.br/pdf/tce/v23n2/ pt_0104-0707-tce-23-02-00408.pdf

37. Born R. Desvendando o Planejamento Estratégico. 3. ed. Porto Alegre: Sulina; 2014.

38. Jesus WLA, Assis MMA. Desafios do Planejamento na construção do SUS. Salvador: EDUFBA; 2011. 